\title{
PHYSICAL AND CHEMICAL PROPERTIES OF FOUR IMPORTED WHEAT TO EGYPT
}

\author{
Ayman H. El-Naggar ${ }^{1 *}$, M.A. Abed El-Samie ${ }^{2}$ and S.I. Ghoneim²
}

1. Agricultural Quarantine, Ministry of Agriculture, Egypt.

2. Dept. Food and Diary Sci. and Technol., Fac. Environ. Agric. Sci., Arish Univ., Egypt.

\begin{abstract}
Wheat is one of the most important cereal crops in Egypt. It is consumed at a high level to feed the Egyptian individual because it is relatively cheap compared to other carbohydrate sources. The domestic production of wheat is still insufficient to meet the consumer needs, which increased the food gap of wheat. The overall objective of the present study was to compare and evaluate the wheat of different origins imported to Egypt, and to check the safety of that wheat's to be consumed in Egypt. In this study wheat samples imported from four origin countries including France, Romania, Russia and Ukraine, within five importing intervals including (July-August/2014), (September-October/2014), (November-December/ 2014), (January-February/2015) and the (March-April/2015), used to evaluate imported wheat to Egypt by several tests like moisture content, test weight, falling number, protein content, shrunken and broken grains and insect damaged kernels.. In general the Ukrainian wheat was the beast among all other wheat originated from France, Romania and Russia, Ukrainian wheat came in the first place in three tests i.e. moisture content, that ranged from $10.88 \%$ to $12.43 \%$ with an average of $11.46 \%$., test weight, ranged from 78.77 to $80.57 \mathrm{~kg} \mathrm{hl}^{-1}$ with an average of $79.70 \mathrm{~kg} \mathrm{hl}^{-1}$ and falling number, ranged from 322.0 to $412.0 \mathrm{sec}$ with an average of $360.47 \mathrm{sec}$, and came in the second order in other tests as, protein content, which ranged from 12.21 to $13.67 \%$ with an average $12.80 \%$, shrunken and broken grains ranged from 0.746 to $1.925 \%$ with an average of $1.115 \%$. Ukrainian wheat came in the third order in one test like, insect damaged kernels, which ranged from 0.651 to $0.883 \%$ with an average of $0.761 \%$.
\end{abstract}

Key words: Wheat, chemical and physical properties, test weight, shrunken and broken grains, insect damaged kernels, moisture content, falling number, and protein content.

\section{INTRODUCTION}

Wheat is an important cereal crop world widely as its cultivated area and the amount of produced crop are important issues. Wheat is an important crop because 2.45 billion people (35 percent of the world's population) allover the world depends on it as the main staple food and about 30 million people are engaged in wheat cultivation (Lumpkin, 2011). Wheat is considered the greatest importance among cereals because of its processing

\footnotetext{
* Correspondence Author: + 201004214948

Email: aimanngar@yahoo.com
}

characteristics; it is basically classified into hard, soft, and durum categories. Wheat quality cannot be simply defined since it changes depending on the workers (from the farmer to those in the processing industry) and end use (from flour to bread, pasta, or cookies) (Posner and Hibbs, 2005). Wheat grain is an excellent staple food with numerous nutritional and healthbeneficial compounds (Kimball et al., 2001; Zhao et al., 2009). The nutritional value of wheat is extremely important as it takes an important place among the few 
crop species being extensively grown as staple food sources. The importance of wheat is mainly due to the fact that its seed can be ground into flour; semolina etc. which forms the basic ingredients of bread and other bakery products, as well as pasta and thus it presents the main sources of nutrients to the most of the world populations (Sramkova et al., 2009).

Physical evaluation of the wheat kernels offers a first and interesting quality control for selection as raw materials because the kernel physical features are related with design of equipment, handling, aeration and storage as well as to end use. Increasingly, analyses are implemented to assess the inherent characteristics of the grain to better know their attributes. The study of wheat kernel characteristics is necessary because new cultivars (with new and different properties) are constantly being bred and produced (Babić et al., 2011). El-Fawal et al. (2009) cited that the physical quality of the kernel plays an important role for identifying the engineering characteristics of cereal crop grains.

Test weight has been used as a quality parameter of cereals in a large number of countries and is still employed to determine the price level (Kleijer et al., 2007). Wheat grading systems strongly rely on HLM (Hectoliter mass) as a guide to wheat grain quality. Producers are remunerated according to the HLM value of their wheat before other factors such as protein content is taken into consideration. An increase in HLM results in a higher allocated grade and subsequently in a higher price per ton of wheat unless other grade determining factors such as protein. The HLM values of sound wheat normally vary from 70 to $85 \mathrm{~kg} \mathrm{hl}^{-1}$, but can be higher or lower due to environmental conditions and insect damage (Manley et al., 2009). The individual grading factors that were determined by FGIS were dockage, actual dockage, moisture, test weight per bushel, total damaged kernels, foreign material, shrunken and broken kernels, total defects, and total fusarium (scab) damage (Odette et al., 1985).

One of the most relevant wheat kernel quality parameters is insect damage. This particular assessment is considered one of the most critical degrading factors (El-Naggar and Mikhaiel, 2011), because it relates to flour yield and color and increases the amounts of insect fragments present in flours and processed products which are considered as one of the most important quality factors related to food sanitation. Presence of insects induces losses in quantity and quality by insect consumption, grain weight loss, contamination (toxicity) with excrement, bodily fragments and chemical secretions that disfavor flour flavor and odor. In addition, insects increase heat and kernel moisture due to their metabolic activity. The potent enzymes produced by insects and by the grain respiration system are known to negatively affect milling and baking qualities (Singh et al., 2010; Brabec et al., 2015).

Determining moisture content is an essential first step in analyzing wheat or flour quality since this data is used for other tests. Flour millers adjust the moisture in wheat to a standard level before milling (Husejin et al., 2008). Wheat or flour with low moisture content is more stable during storage. Moisture content can be an indicator of profitability in milling (Trajković et al., 1983).

Hagberg (1960,1961) and Perten (1964) developed the falling number method as a simple and rapid technique for determining a-amylase activity using wheat meal as the native substrate. Subsequently, this method has become the international standard (ICC, 1968; AACC, 1972) that is used widely in grain classification, quality control and marketing. Grain with a low falling number due to high a-amylase activity causes substantial economic losses to growers, significant processing and storage problems and is generally reflected 
in poorer quality end-products (Derera, 1989; Edwards et al., 1989).Protein content is one of the most important standards for measuring wheat quality (Natalja et al., 2016). Protein content is traditionally recognized as the most influential factor affecting wheat bread making quality (Shewry et al., 1986). The importance of protein content lies in the ability of gluten to produce dough with the desired rheological properties (Ktenioudaki et al., 2010).A wide gap in self-sufficiency between the production and consumption of food occurred in the light of the increasing population, rising standards of living, declining of trade in food grains and high prices in the market (Gerber, 2014).

\section{MATERIALS AND METHODS}

Four types of imported wheat were used in their assessment, namely French wheat, Romanian wheat, Russian wheat and Ukrainian wheat. Samples were drawn from imported wheat shipments when they reached the ports of (Alexandria, El Dekhela and Damietta), the biggest ports in Egypt receiving imported wheat. The samples drawn in five importing intervals including $1^{\text {st }}$ interval (July-August/2014), $2^{\text {nd }}$ interval (September-October/2014), $3^{\text {rd }}$ interval (November-December/2014), $4^{\text {th }}$ interval (January-February/2015) and the $5^{\text {th }}$ interval (March-April / 2015).

\section{Test Weight}

Test weight was measured in special Seedburo Filling Hopper (model 151) according to (AACC, 2000), method No. 55-10. After cleaning and passing through specific sieves, the hopper was filled with the sample. Excess grains were scraped off with a strike. Reading was noted and result calculated as $\mathrm{kg} \mathrm{hl}^{-1}$.

\section{Shrunken and Broken Grains}

A shrunken and broken kernel is a grading factor for wheat. To determine shrunken and broken kernels in wheat, the inspector places 250 grams on a $0.064 \times 3 / 8$ inch $(1.626 \mathrm{~mm} \times 9.545 \mathrm{~mm})$ oblong-hole sieve and mechanically shakes the sieve 30 times from side to side. The machine used to sieve the sample, a Strand Sizer, with a stroke counter and always starts and stops in the same position. One complete stroke takes approximately 1 second (Grain Inspection Handbook, 2014).

Shrunken and broken kernels (\%) = Weight of Shrunken and broken kernels sample in $250 \mathrm{~g} \times 4 \times 100 / 1000$

\section{Insect Damaged Kernels}

Determine insect-damaged kernels on a representative portion of dockage free and shrunken and broken-free wheat. Insect damaged kernels are kernels bored or tunneled by insects (Grain Inspection Handbook, 2014).

Insect damaged kernels $(\%)=$ Weight of Insect damaged kernels sample in $250 \mathrm{~g} \times 4$ $\times 100 / 1000$

\section{Wheat Milling}

Wheat samples milling through a Buhler, MLU-202, pneumatic mill according to AACC (2000) method No. 26-31.

\section{Moisture Content}

Moisture was determined according to AACC (2000) method No. 44-19. Two grams flour was placed in preheated and weighed metallic dish and dried in a hot air oven at $130^{\circ} \mathrm{C}$ for 2 hours or till constant weight. The loss in weight was calculated as percentage of moisture content.

\section{Falling Number}

Falling number was determined by using instrument "Falling No.1600" according to AACC (2000) method No. 02-06. A 7 gram sample of ground wheat or flour is weighed and combined with $25 \mathrm{ml}$ of distilled water in a glass falling number tube with a stirrer and shaken to form slurry. As the slurry is heated in a boiling water bath at $100^{\circ} \mathrm{C}$ and stirred constantly, the starch gelatinizes and 
forms a thick paste. The time it takes the stirrer to drop through the paste is recorded as the falling number value.

\section{Protein Content}

Protein content of whole wheat was determined using the Kjeldahl Tecator System (AACC, 2000). The protein content can be calculated as follows:

Protein content $(\%)=\mathrm{N}$ (nitrogen) $(\%) \times$ 5.7 (stationary factor for whole wheat).

\section{Statistical Analysis}

Data analyzed by using completely randomized design (analysis of variance) and producer using MSTAT-C package differences pattern (Michigan university, 1983). Means were compared by using each of least significant differences (LSD) (Steel and Torrie, 1980) and Dunkan's multiple range test (Duncan, 1955) at the 5\% level.

\section{RESULTS AND DISCUSSION}

\section{Test Weight}

Imported wheat samples from four origin countries including France, Romania, Russia and Ukraine, within five importing intervals including $1^{\text {st }}$ interval (JulyAugust/2014), $2^{\text {nd }}$ interval (SeptemberOctober/2014), $3^{\text {rd }}$ interval (NovemberDecember/2014), $4^{\text {th }}$ interval (JanuaryFebruary/2015) and the $5^{\text {th }}$ interval (MarchApril/2015) were evaluated for their Test weight and were all recorded as $\mathrm{kg} \mathrm{hl}^{-1}$ in Table 1. From results in Table 1, It is clear that, test weight of Ukrainian wheat was the highest, comparing to all other wheat originated from France, Romania and Russia, as the Ukrainian wheat samples' Test weight ranged from $(78.17-80.57 \mathrm{~kg}$ $\mathrm{hl}^{-1}$ ) with an average of $79.70 \mathrm{~kg} \mathrm{hl}^{-1}$ comparing to $79.47,78.45$ and $79.35 \mathrm{~kg} \mathrm{hl}^{-1}$ for Russian, Romanian and French wheat samples respectively. Within the Ukrainian wheat samples, $5^{\text {th }}$ interval got the biggest
Test weight $\left(80.57 \mathrm{~kg} \mathrm{hl}^{-1}\right)$ while $4^{\text {th }}$ interval scored the minimum Test weight $(78.17 \mathrm{~kg}$ $\mathrm{hl}^{-1}$ ).Minimum Test weight was obtained with the Russian wheat in the $3^{\text {rd }}$ interval $\left(78.11 \mathrm{~kg} \mathrm{~h}^{-1}\right)$ with range of $(78.11-80.49 \mathrm{~kg}$

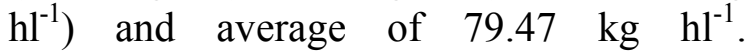
Maximum Test weight of Russian wheat was 80.15 and $80.49 \mathrm{~kg} \mathrm{hl}^{-1}$ for the $2^{\text {nd }}$ and $4^{\text {th }}$ intervals respectively.

Test weight of the imported Romanian wheat was in the range 78.27-78.71 kg hl${ }^{-1}$ with an average of $78.45 \mathrm{~kg} \mathrm{hl}^{-1}$ which was the least Test weight comparing to all other importing country. Within this wheat samples imported from Romania, fifth interval scored the maximum Test weight $\left(78.71 \mathrm{kghl}^{-1}\right)$, followed by fourth interval with score $\left(78.43 \mathrm{~kg} \mathrm{hl}^{-1}\right)$. Second and third intervals were significantly same in score $\left(78.41 \mathrm{~kg} \mathrm{hl}^{-1}\right)$. Minimum Test weight in the Romanian wheat was scored by sample of first interval $78.27 \mathrm{~kg} \mathrm{hl}^{-1}$ and that was the least Test weight among all imported wheat samples.

Test weight of the imported French wheat was in the range 78.59-80.25 $\mathrm{kg} \mathrm{h}^{-1}$ with an average of $79.35 \mathrm{~kg} \mathrm{hl}^{-1}$. Within this wheat origin country (France) fourth interval scored the maximum Test weight $\left(80.25 \mathrm{~kg} \mathrm{~h}^{-1}\right)$ followed by third interval with score $\left(79.74 \mathrm{~kg} \mathrm{hl}^{-1}\right)$ second and fifth intervals came bellow with significant difference in between with (79.09 and $79.07 \mathrm{~kg} \mathrm{hl}^{-1}$ ) respectively. Minimum Test weight was scored for first interval sample ( $78.59 \mathrm{~kg} \mathrm{hl}^{-1}$ ). Looking for these data and for the information that test weight is the quantity (measured in mass or weight) of wheat that can be contained in a standard volume, so it could be concluded that Romanian is better than other wheat especially in interval one imported from July to August. and looking for importing periods, no significant differences were noticed. 
SINAI Journal of Applied Sciences (ISSN: 2314-6079), Vol. (7), Is. (1), Apr. 2018

Table (1): Test weight of four imported wheat in five intervals from Jul. 2014 to Apr. $2015\left(\mathrm{~kg} \mathrm{hl}^{-1}\right)$.

\begin{tabular}{|c|c|c|c|c|c|c|}
\hline \multirow[t]{2}{*}{ Origin } & \multicolumn{5}{|c|}{ Interval } & \multirow{2}{*}{$\begin{array}{c}\text { Interval mean } \\
\quad \pm \mathrm{SD}\end{array}$} \\
\hline & Jul. Aug. & Sep. Oct. & Nov. Dec. & Jan. Feb. & Mar. Apr. & \\
\hline French Wheat & $78.59^{\mathrm{fg}} \pm 0.87^{1}$ & $79.09^{\mathrm{ef}} \pm 1.10$ & $79.74^{b-d} \pm 0.41$ & $80.25^{\mathrm{ab}} \pm 1.00$ & $79.07^{\mathrm{ef}} \pm 0.93$ & $79.35^{\mathrm{a}} \pm 0.97$ \\
\hline Romanian wheat & $78.27^{\mathrm{g}} \pm 0.15$ & $78.41^{\mathrm{g}_{ \pm}} 0.65$ & $78.41^{\mathrm{g}} \pm 0.04$ & $78.43^{\mathrm{g}} \pm 0.57$ & $78.71^{\mathrm{fg}} \pm 0.52$ & $78.45^{b} \pm 0.41$ \\
\hline Russian wheat & $79.52^{\mathrm{de}} \pm 0.76$ & $80.15^{\mathrm{a}-\mathrm{c}} \pm 1.18$ & $78.11^{\mathrm{g}} \pm 0.12$ & $80.49^{\mathrm{a}} \pm 0.15$ & $79.09^{\mathrm{ef}} \pm 0.42$ & $79.47^{\mathrm{a}} \pm 1.03$ \\
\hline Ukrainian wheat & $79.57^{\mathrm{c}-\mathrm{e}} \pm 0.38$ & $80.08^{\mathrm{a}-\mathrm{d}} \pm 0.35$ & $80.10^{\mathrm{a}-\mathrm{d}} \pm 0.20$ & $78.17^{\mathrm{g}} \pm 1.37$ & $80.57^{\mathrm{a}} \pm 0.76$ & $79.70^{\mathrm{a}} \pm 1.06$ \\
\hline Interval mean $\pm \mathrm{SD}$ & $78.99^{a} \pm 0.79$ & $79.43^{a} \pm 1.07$ & $79.09^{\mathrm{a}} \pm 0.91$ & $79.34^{\mathrm{a}} \pm 1.33$ & $79.36^{\mathrm{a}} \pm 0.95$ & $79.24 \pm 1.01$ \\
\hline \multicolumn{7}{|c|}{ LSD 0.05} \\
\hline \multicolumn{2}{|c|}{ Among [Origin (O.)] } & \multicolumn{2}{|c|}{ Among [interval (I.)] } & \multicolumn{3}{|c|}{ Interaction (O. X I.) } \\
\hline \multicolumn{2}{|l|}{$0.82 * *$} & \multicolumn{2}{|c|}{$0.80 \mathrm{~ns}$} & \multicolumn{3}{|c|}{$0.63 * *$} \\
\hline
\end{tabular}

- Data are expressed as means (3 replicates) $\pm \mathrm{SD}$

- Averages of origin in the same column having the same superscripts are not significantly different, same averages in interval raw which having same superscripts are not significantly different at $\mathrm{P} \leq 0.05$.

The ranges of Romanian wheat was considered as good wheat as these results are in line with the results of Protic et al. (2007) who found that test weight was under $80 \mathrm{~kg} \mathrm{hl}^{-1}$. The test weight of this wheat was also same to the Egyptian wheat which ranged from 77-78 $\mathrm{kg} \mathrm{hl}^{-1}$ (Geoff Honey, 2010).

EOS (2015) states that Test weight should not less than $74 \mathrm{~kg} . \mathrm{hl}^{-1}$, and the results indicated that all wheat from Ukraine, Russia, Romania and France were acceptable imported wheat, and the Ukrainian wheat was the highest, comparing to all other wheat originated from France, Romania and Russia.

\section{Shrunken and Broken Grains}

Shrunken and broken grains of wheat samples, imported from four origin countries including France, Romania, Russia and Ukraine, within five importing intervals including $1^{\text {st }}$ interval (July-August/2014), $2^{\text {nd }}$ interval (September-October/2014), $3^{\text {rd }}$ interval (November-December/2014), $4^{\text {th }}$ interval (January-February/2015) and the $5^{\text {th }}$ interval (March-April/2015) were all recorded as percentage and were presented in Table 2. Minimum Shrunken and broken grains percentage was obtained by the French wheat sample especially in the fifth interval with score $(0.048 \%)$. Shrunken and broken grains percentages of the imported French wheat were in the range of 0.048 to $0.917 \%$ and an average of $0.658 \%$.

Shrunken and broken grains of Romanian and Ukrainian wheat showed ranges of 0.849 to $1.403 \%$ and 0.746 to $1.925 \%$ and an average of 1.210 and $1.115 \%$ respectively.

Maximum Shrunken and broken grains were obtained by the Russian wheat samples with a range of $1.143-2.613 \%$ and an average of $1.681 \%$, and maximum Shrunken and broken grains were that of $2^{\text {nd }}$ interval $(2.613 \%)$.

Fifth interval was the least average $0.959 \%$ in Shrunken and broken grains followed by third and fourth intervals and maximal scores were those of the first and second intervals with scores of 1.407 and $1.320 \%$, respectively. This results are in agreement with the results of Michael et al. (2005) who reported a range of 1.4 to $1.6 \%$ 
Table (2): Shrunken and broken grains of four imported wheat in five intervals from Jul. 2014 to Apr. 2015 (\%)

\begin{tabular}{lcccccc}
\hline Origin & \multicolumn{3}{c}{ Interval } & Interval \\
\cline { 2 - 6 } & Jul. Aug. & Sep. Oct. & Nov. Dec. & Jan. Feb. & Mar. Apr. & \\
\hline French wheat & $0.741^{\mathrm{hi}} \pm 0.006^{\mathrm{l}}$ & $0.705^{\mathrm{i}} \pm 0.016$ & $0.917^{\mathrm{f-}} \pm 0.040$ & $0.880^{\mathrm{g-1}} \pm 0.059$ & $0.048^{\mathrm{j}} \pm 0.013$ & $0.658^{\mathrm{c}} \pm 0.328$ \\
Romanian wheat & $1.351^{\mathrm{c}-\mathrm{f}} \pm 1.008$ & $1.216^{\mathrm{d}-\mathrm{g}} \pm 0.253$ & $0.849^{\mathrm{g}-\mathrm{i}} \pm 0.126$ & $1.403^{\mathrm{ce}} \pm 0.061$ & $1.233^{\mathrm{d}-\mathrm{g}} \pm 0.093$ & $1.210^{\mathrm{b}} \pm 0.446$ \\
Russian wheat & $1.610^{\mathrm{b}-\mathrm{d}} \pm 0.080$ & $2.613^{\mathrm{a}} \pm 0.147$ & $1.260^{\mathrm{d}-\mathrm{g}} \pm 0.032$ & $1.143^{\mathrm{e}-\mathrm{h}} \pm 0.061$ & $1.779^{\mathrm{bc}} \pm 0.026$ & $1.681^{\mathrm{a}} \pm 0.543$ \\
Ukrainian wheat & $1.925^{\mathrm{b}} \pm 0.055$ & $0.746^{\mathrm{h}} \pm 0.006$ & $1.056^{\mathrm{e-}} \pm 0.007$ & $1.075^{\mathrm{e-}} \pm 0.058$ & $0.775^{\mathrm{hi}} \pm 0.041$ & $1.115^{\mathrm{b}} \pm 0.444$ \\
Interval mean \pm SD & $1.407^{\mathrm{a}} \pm 0.627$ & $1.320^{\mathrm{ab}} \pm 0.817$ & $1.021^{\mathrm{c}} \pm 0.174$ & $1.125 \mathrm{~b}^{\mathrm{c}} \pm 0.202$ & $0.959^{\mathrm{c}} \pm 0.664$ & $1.166 \pm 0.570$ \\
LSD 0.05 & & & & & &
\end{tabular}

Among [Origin (O.)]

$0.285 * *$
Among [interval (I.)]

$0.278^{* *}$
Interaction (O. X I.)

$0.436 * *$

- Data are expressed as means (3 replicates) $\pm \mathrm{SD}$

- Averages of origin in the same column having the same superscripts are not significantly different, same averages in interval raw which having same superscripts are not significantly different at $\mathrm{P} \leq 0.05$.

EOS (2015) states that Shrunken and broken grains should not exceed 5\% max, and the obtained results assured that all imported wheats from Jul. 2014 to Apr. 2015 and all wheats from Ukraine, Russia, Romania and France are acceptable. French and Ukrainian wheat achieved lowest level with an average of 0.658 and $1.115 \%$, respectively.

\section{Insect Damaged Kernels}

Insect damaged kernels of wheat samples, imported from four origin countries including France, Romania, Russia and Ukraine, within five importing intervals including $1^{\text {st }}$ interval (July-August/2014), $2^{\text {nd }}$ interval (September-October/2014), $3^{\text {rd }}$ interval (November-December/2014), $4^{\text {th }}$ interval (January-February/2015) and the $5^{\text {th }}$ interval (March-April / 2015) were all recorded as percentage and were presented in Table 3.

Minimum insect damaged kernels was obtained by the French wheat sample in fourth interval with score $0.026 \%$ and with a range of 0.026 to $1.233 \%$ and an average of $0.402 \%$. Maximum insect damaged kernels were that of $3^{\text {rd }}$ interval (Jan. /Feb, 2015) $1.233 \%$.
Insect damaged kernels of Russian wheat came bellow French of all with range of $0.154 \%$ to $1.148 \%$ with an average of $0.434 \%$ comparing to averages of 0.761 and $0.843 \%$ for Ukrainian and Romanian wheat samples, respectively. Within the Russian wheat samples, $1^{\text {st }}$ and $2^{\text {nd }}$ intervals got low insect damaged kernels with similar score $0.154 \%$ while $3^{\text {rd }}$ interval was the maximum insect damaged kernels $1.148 \%$.

Insect damaged kernels of the imported Ukrainian wheat was in the range 0.651 to $0.883 \%$ with an average of $0.761 \%$.Within this wheat origin (Ukraine) first interval scored the minimum insect damaged kernels $0.651 \%$. Maximum insect damaged kernels were scored by sample of third interval with score $0.883 \%$.

Maximum insect damaged kernels were obtained by the Romanian wheat samples with a range of 0.440 to $1.192 \%$ and an average of $0.843 \%$, and minimum insect damaged kernels were that of $1^{\text {st }}$ interval $0.440 \%$. This results are in agreement with the results of Michael et al. (2005) who reported a range of 0.7 to $1.0 \%$. 
SINAI Journal of Applied Sciences (ISSN: 2314-6079), Vol. (7), Is. (1), Apr. 2018

Table (3): Insect damaged kernels of four imported wheat in five intervals from Jul 2014 to Apr 2015 (\%)

\begin{tabular}{|c|c|c|c|c|c|c|}
\hline \multirow[t]{2}{*}{ Origin } & \multicolumn{5}{|c|}{ Intervals } & \multirow{2}{*}{$\begin{array}{c}\text { Interval mean } \\
\quad \pm \mathrm{SD}\end{array}$} \\
\hline & Jul. /Aug. & Sep. / Oct. & Nov. / Dec. & Jan. / Feb. & Mar. / Apr. & \\
\hline French Wheat & $0.044^{\mathrm{h}} \pm 0.0009^{1}$ & $0.352^{\mathrm{fg}} \pm 0.0082$ & $1.233^{\mathrm{a}} \pm 0.0663$ & $0.026^{\mathrm{h}} \pm 0.0053$ & $0.357^{\mathrm{fg}} \pm 0.0023$ & $0.402^{\mathrm{b}} \pm 0.4552$ \\
\hline Romanian wheat & $0.440^{\mathrm{ef}} \pm 0.0138$ & $0.872^{\mathrm{cd}} \pm 0.0095$ & $1.192^{\mathrm{ab}} \pm 0.0172$ & $0.761^{\mathrm{cd}} \pm 0.0601$ & $0.949^{\mathrm{bc}} \pm 0.0044$ & $0.843^{\mathrm{a}} \pm 0.2561$ \\
\hline Russian wheat & $0.154^{\mathrm{gh}} \pm 0.0206$ & $0.154^{\text {gh }} \pm 0.0057$ & $1.148^{\mathrm{ab}} \pm 0.0040$ & $0.392^{\mathrm{fg}} \pm 0.0046$ & $0.322^{\mathrm{fg}} \pm 0.0057$ & $0.434^{\mathrm{b}} \pm 0.3821$ \\
\hline Ukrainian wheat & $0.651^{\mathrm{de}} \pm 0.0275$ & $0.723^{\mathrm{cd}} \pm 0.5730$ & $0.883^{\mathrm{cd}} \pm 0.0523$ & $0.710^{\mathrm{cd}} \pm 0.2247$ & $0.837^{\mathrm{cd}} \pm 0.0043$ & $0.761^{\mathrm{a}} \pm 0.2500$ \\
\hline Interval mean \pm SD & $0.322^{\mathrm{c}} \pm 0.2494$ & $0.525^{b} \pm 0.3858$ & $1.114^{\mathrm{a}} \pm \mathbf{0 . 1 4 7 7}$ & $0.472^{\mathrm{bc}} \pm 0.3226$ & $0.616^{b} \pm 0.2923$ & $0.610 \pm 0.3910$ \\
\hline \multicolumn{7}{|l|}{ LSD 0.05} \\
\hline \multicolumn{2}{|c|}{ Among [Origin (O.)] } & \multicolumn{3}{|c|}{ Among [interval (I.)] } & \multicolumn{2}{|c|}{ Interaction (O. X I.) } \\
\hline \multicolumn{2}{|c|}{$0.1643 * *$} & \multicolumn{3}{|c|}{$0.1603 * *$} & \multicolumn{2}{|c|}{$0.2516 * *$} \\
\hline
\end{tabular}

- Data are expressed as means (3 replicates) $\pm \mathrm{SD}$

- Averages of origin in the same column having the same superscripts are not significantly different, same averages in interval raw which having same superscripts are not significantly different at $\mathrm{P} \leq 0.05$.

EOS (2015) states that Insect damaged kernels should not exceed $1.5 \%$ max. The obtained results confirmed that all imported wheats from Jul. 2014 to Apr. 2015 are acceptable, but the first interval from Jul/Aug 2014 was the best one.

\section{Moisture Contents}

Moisture contents of wheat samples, imported from four origin countries including France, Romania, Russia and Ukraine, within five importing intervals were all recorded as percentage and were presented in Table 4 and Fig. 1

The results indicated that, moisture contents of Ukrainian wheat was the least among all other wheat originated from France, Romania and Russia, as the Ukrainian wheat samples' moisture contents ranged from $10.88 \%$ to $12.43 \%$ with an average of $11.46 \%$ comparing to 11.57 , 12.34 and $12.51 \%$ for Russian, Romanian and French wheat samples, respectively. Within the Ukrainian wheat samples, $1^{\text {st }}$ interval got the lowest moisture contents $(10.88 \%)$ while $3^{\text {rd }}$ interval was the maximum moisture content $(12.43 \%)$.
Russian wheat samples' moisture contents were in harmong to the Ukrainian wheat samples with an average of $11.57 \%$. Third and fifth intervals got the lowest moisture contents (11.47 and $11.48 \%$ ) respectively, while second interval was the maximum $(11.70 \%)$.

Moisture contents of the imported Romanian wheat was in the range 11.44$12.65 \%$ within an average of $12.34 \%$. Within this wheat origin country (Romania), first interval scored the minimum moisture contents (11.44\%) followed by both second and fifth intervals with no significant differences with scores (12.48 and 12.54\%), respectively, maximum moisture contents were scored by samples of third and fourth intervals with scores of 12.65 and $12.60 \%$, respectively.

Maximum moisture contents were obtained by the French wheat samples with a range of $12.15-13.00 \%$, and an average of $12.51 \%$. Minimum moisture contents was that of $4^{\text {th }}$ and $5^{\text {th }}$ intervals (12.15 and $12.21 \%$ ) respectively, and maximum moisture content was that of the $1^{\text {st }}$ interval $(13.00 \%)$. 
Table (4): Moisture content of four imported wheat in five intervals from Jul. 2014 to Apr. $2015(\%)$

\begin{tabular}{|c|c|c|c|c|c|c|}
\hline \multirow[t]{2}{*}{ Origin } & \multicolumn{5}{|c|}{ Interval } & \multirow{2}{*}{$\begin{array}{c}\text { Interval } \\
\text { mean } \pm \text { SD }\end{array}$} \\
\hline & Jul. / Aug. & Sep. / Oct. & Nov. / Dec. & Jan. / Feb. & Mar. / Apr. & \\
\hline French Wheat & $13.00^{\mathrm{a}} \pm 1.00^{\mathrm{T}}$ & $12.77^{\mathrm{ab}} \pm 1.08$ & $12.42^{\mathrm{a}-\mathrm{c}} \pm 0.07$ & $12.15^{b-e} \pm 0.18$ & $12.21^{\mathrm{b}-\mathrm{d}} \pm 0.05$ & $12.51^{\mathrm{a}} \pm 0.66$ \\
\hline Romanian wheat & $11.44^{\mathrm{fg}} \pm 0.13$ & $12.48^{\mathrm{a}-\mathrm{c}} \pm 0.43$ & $12.65^{\mathrm{ab}} \pm 0.09$ & $12.60^{\mathrm{ab}} \pm 0.04$ & $12.54^{\mathrm{a}-\mathrm{c}} \pm 0.09$ & $12.34^{\mathrm{a}} \pm 0.50$ \\
\hline Russian wheat & $11.63^{\mathrm{d}-\mathrm{f}} \pm 0.25$ & $11.70^{\mathrm{d}-\mathrm{f}} \pm 0.03$ & $11.47^{\mathrm{e}-\mathrm{g}} \pm 0.13$ & $11.58^{\mathrm{d}-\mathrm{f}} \pm 0.05$ & $11.48^{\mathrm{e}-\mathrm{g}} \pm 0.08$ & $11.57^{\mathrm{b}} \pm 0.15$ \\
\hline Ukrainian wheat & $10.88^{\mathrm{g}} \pm 0.06$ & $11.85^{\mathrm{c-f}} \pm 0.06$ & $12.43^{\mathrm{a}-\mathrm{c}} \pm 0.62$ & $11.23^{\mathrm{fg}} \pm 0.31$ & $10.89^{\mathrm{g}} \pm 0.06$ & $11.46^{\mathrm{b}} \pm 0.67$ \\
\hline Interval mean $\pm \mathrm{SD}$ & $11.74^{\mathrm{c}} \pm 0.93$ & $12.20^{\mathrm{ab}} \pm 0.68$ & $12.24^{\mathrm{a}} \pm 0.55$ & $11.89^{\mathrm{a}-\mathrm{c}} \pm 0.57$ & $11.78^{\mathrm{bc}} \pm 0.67$ & $11.97 \pm 0.70$ \\
\hline \multicolumn{7}{|l|}{ LSD 0.05} \\
\hline \multicolumn{2}{|c|}{ Among [Origin (O.)] } & \multicolumn{3}{|c|}{ Among [interval (I.)] } & \multicolumn{2}{|c|}{ Interaction (O. X I.) } \\
\hline \multicolumn{2}{|c|}{$0.45 * *$} & \multicolumn{3}{|c|}{$0.44 *$} & \multicolumn{2}{|l|}{$0.69 * *$} \\
\hline
\end{tabular}

- Data are expressed as means (3 replicates) $\pm \mathrm{SD}$

- Averages of origin in the same column having the same superscripts are not significantly different, same averages in interval raw which having same superscripts are not significantly different at $\mathrm{P} \leq 0.05$.

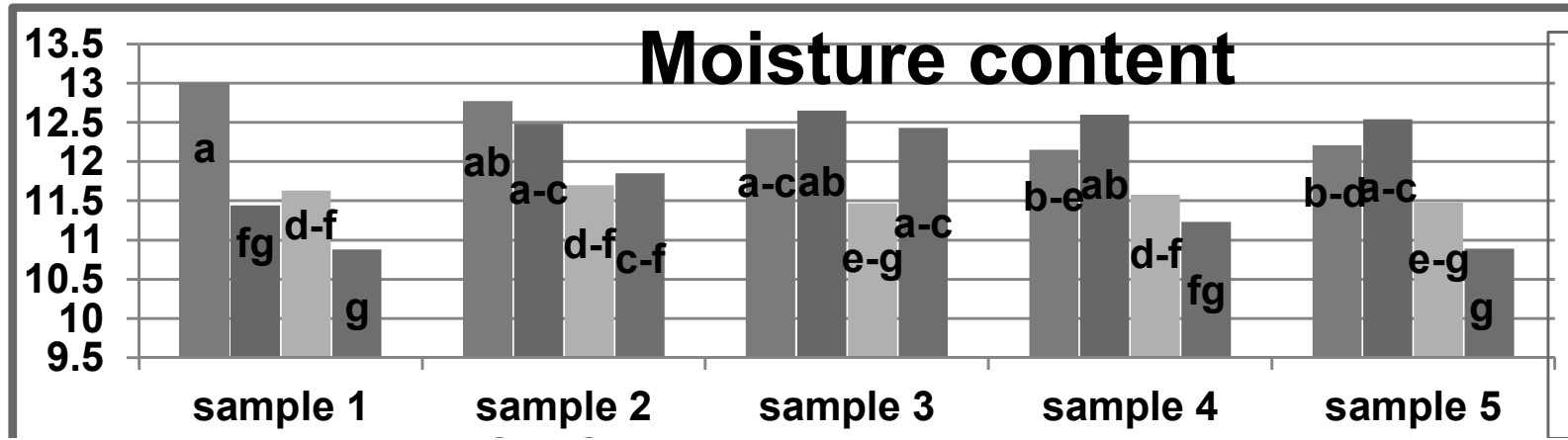

Fig. (1): Moisture content (\%) of four imported wheat in five intervals from Jul. 2014 to Apr. 2015.

Wheat or flour with high moisture content (greater than 14.5 percent) attracts mold, bacteria and insects, all of which cause deterioration during storage. Wheat or flour with low moisture content is more stable during storage. Moisture content can be an indicator of profitability in milling (Trajković et al., 1983 Husejin, et al., 2008). Temperatures between 30 and $35^{\circ} \mathrm{C}$ and moisture content in the grain above $15 \%$ are the conditions for the optimal development of fungi in storage (Chelladurai et al., 2010).

EOS (2015) states that moisture content should not exceed $13.5 \% \max$, and the results indicated that all intervals from Jul. 2014 to Apr. 2015 are acceptable imported wheat but the first interval from Jul./Aug 2014 is the best one.

\section{Falling Number}

Falling Number is a test, gives an indication of the amount of sprout damage that has occurred within a wheat sample. Generally, a falling number value of 350 seconds or longer indicates a low enzyme activity and very sound wheat quality. As the amount of enzyme activity increases, the falling number decreases. Values below 200 seconds indicate high levels of enzyme activity (German, 2006). 
Falling number of all imported wheat samples, imported from France, Romania, Russia and Ukraine, within five importing intervals around the year except the Egyptian wheat production intervals were all recorded in seconds and were presented in Table 5.

Results in Table 5 show that, falling number of Ukrainian and Russian wheat was the least among all other wheat originated with no significant differences between them, including wheat imported from France, Romania and Russia, Russia and Ukraine. Falling number of wheat samples imported from Ukraine was in the range of 322.0 to $412.0 \mathrm{sec}$ with an average of $360.47 \mathrm{sec}$ with no differences significantly with the Russian wheat which ranged from 324.67 to $397 \mathrm{sec}$ with an average of $352.13 \mathrm{sec}$ which was both higher comparing to 325.60 and $290.40 \mathrm{sec}$ for the Romanian and French wheat samples, respectively. Within the Ukrainian wheat samples, $5^{\text {th }}$ interval got the maximum falling number score $(412.0 \mathrm{sec})$ while $2^{\text {nd }}$ interval got the minimum falling number score $(322.0 \mathrm{sec})$.

Falling number of the imported Romanian wheat was in the range $(273.33-399.0 \mathrm{sec})$ with an average of $(325.60 \mathrm{sec}$.) of the Romanian wheat samples, first interval scored the maximum falling number (399.0 sec.) followed by both fourth and fifth intervals with no significant differences between them scores ( 325.33 and $317.0 \mathrm{sec}$.) respectively, minimum falling number were scored by samples of third and second intervals with scores of (273.33 and 313.33 sec.), respectively.

Minimum falling number were obtained by the French wheat samples with a range of 259.33-342.33 sec and an average of $290.40 \mathrm{sec}$. maximum falling number in the French wheat samples was that of the $3^{\text {rd }}$ and $5^{\text {th }}$ intervals (342.33 and $314.0 \mathrm{sec}$.), respectively and minimum falling number was that of the $2^{\text {nd }}$ interval $(259.33 \mathrm{sec}$.).

Interval 5 had the highest ranges of falling number scores with an average of $360.00 \mathrm{sec}$ while interval 2 was lower values with an average of $307.67 \mathrm{sec}$.

French wheat samples with its lowest falling number average $(290.40 \mathrm{sec})$ was an average of quality because the standards of falling number ranges from 200 to 350 seconds as mentioned before, and our range (259.33-412.00) was in agreement with the data of Finney (1985) who reported a range of 222 to 450 seconds.

EOS (2015) states that falling number should not less than $230 \mathrm{sec}$, and the results indicated that all wheat's from Ukraine, Russia, Romania and France is acceptable imported wheats, and the Ukrainian wheat was the highest, comparing to all other wheat's originated from France, Romania and Russia, in the range of 322.0 to 412.0 sec with an average of $360.47 \mathrm{sec}$.

\section{Protein Contents}

Wheat samples imported from France, Romania, Russia and Ukraine within July 2014 to April 2015 imported to Egypt in five intervals are analyzed for their protein contents percentages and recorded in Table 6. The protein contents were determined because it is one of the main quality characteristics for the evaluation of imported wheat especially because it is mainly used to produce baladi bread and especially gluten is a key factor in producing bread. Hard and high proteincontaining wheat is of high quality and suitable for making bread (Snape et al., 2005).

Results in Table 6 demonstrat that, protein content of the imported wheat was 
Table (5): Falling number (sec) of four imported wheat in five intervals from Jul. 2014 to Apr. 2015.

\begin{tabular}{|c|c|c|c|c|c|c|}
\hline \multirow[t]{2}{*}{ Origin } & \multicolumn{5}{|c|}{ Interval } & \multirow{2}{*}{$\begin{array}{c}\text { Interval mean } \\
\quad \pm \mathrm{SD}\end{array}$} \\
\hline & Jul. / Aug. & Sep. / Oct. & Nov. / Dec. & Jan. / Feb. & Mar. / Apr. & \\
\hline French Wheat & $260.33^{i 1} \pm 2.52^{1}$ & $259.33^{j} \pm 1.15$ & $342.33^{\mathrm{de}} \pm 9.50$ & $276.00^{h} \pm 4.58$ & $314.00^{\mathrm{g}} \pm 5.29$ & $290.40^{\mathrm{c}} \pm 34.11$ \\
\hline Romanian wheat & $399.00^{\mathrm{ab}} \pm 8.54$ & $313.33^{\mathrm{g}} \pm 17.21$ & $273.33^{\mathrm{hi}} \pm 7.23$ & $325.33^{\mathrm{fg}} \pm 4.04$ & $317.00^{\mathrm{g}} \pm 3.61$ & $325.60^{\mathrm{b}} \pm 43.04$ \\
\hline Russian wheat & $354.67^{\mathrm{d}} \pm 4.51$ & $336.00^{\mathrm{ef}} \pm 3.61$ & $324.67^{\mathrm{fg}_{ \pm}} \pm 4.16$ & $348.33^{\mathrm{de}} \pm 7.02$ & $397.00 b^{c} \pm 6.24$ & $352.13^{\mathrm{a}} \pm 25.94$ \\
\hline Ukrainian wheat & $385.67^{\mathrm{c}} \pm 8.96$ & $322.00^{\mathrm{g}} \pm 2.00$ & $336.67^{\mathrm{ef}^{\mathrm{f}}} \pm 3.51$ & $346.00^{\mathrm{de}} \pm 10.82$ & $412.00^{\mathrm{a}} \pm 11.36$ & $360.47^{\mathrm{a}} \pm 35.18$ \\
\hline Interval mean $\pm \mathbf{S D}$ & $349.92^{\mathrm{b}} \pm 56.86$ & $307.67^{\mathrm{d}} \pm 31.27$ & $319.25^{\mathrm{c}} \pm 29.02$ & $323.92^{\mathrm{c}} \pm 30.97$ & $360.00^{\mathrm{a}} \pm 47.22$ & $332.15 \pm 43.91$ \\
\hline \multicolumn{7}{|l|}{ LSD 0.05} \\
\hline \multicolumn{2}{|c|}{ Among [Origin (O.)] } & \multicolumn{3}{|c|}{ Among [interval (I.)] } & \multicolumn{2}{|c|}{ Interaction (O. X I.) } \\
\hline \multicolumn{2}{|c|}{$8.54 * *$} & \multicolumn{3}{|c|}{$8.33 * *$} & \multicolumn{2}{|c|}{$13.07 * *$} \\
\hline
\end{tabular}

- Data are expressed as means (3 replicates) $\pm \mathrm{SD}$

- Averages of origin in the same column having the same superscripts are not significantly different, same averages in interval raw which having same superscripts are not significantly different at $\mathrm{P} \leq 0.05$.

Table (6): Protein content (\%) of four imported wheat in five intervals from Jul. 2014 to Apr. 2015.

\begin{tabular}{|c|c|c|c|c|c|c|}
\hline \multirow[t]{2}{*}{ Origin } & \multicolumn{5}{|c|}{ Interval } & \multirow{2}{*}{$\begin{array}{c}\text { Interval } \\
\text { mean } \pm \text { SD }\end{array}$} \\
\hline & Jul. /Aug & Sep. / Oct & Nov. / Dec & Jan. / Feb & Mar. / Apr. & \\
\hline French Wheat & $11.53^{1} \pm 0.13^{1}$ & $11.48^{1} \pm 0.22$ & $11.11^{\mathrm{m}} \pm 0.11$ & $11.54^{1} \pm 0.09$ & $11.02^{\mathrm{m}} \pm 0.03$ & $11.34^{\mathrm{c}} \pm 0.26$ \\
\hline Romanian wheat & $13.34^{\mathrm{b}} \pm 0.16$ & $13.23^{\mathrm{bc}} \pm 0.12$ & $13.05^{\mathrm{cd}} \pm 0.04$ & $12.71^{\mathrm{e}} \pm 0.05$ & $12.17^{\mathrm{jk}} \pm 0.05$ & $12.90^{\mathrm{a}} \pm 0.45$ \\
\hline Russian wheat & $12.03^{\mathrm{k}} \pm 0.09$ & $12.40^{\mathrm{gh}} \pm 0.20$ & $12.31^{\mathrm{h}-\mathrm{j}} \pm 0.03$ & $12.38^{\mathrm{hi}} \pm 0.05$ & $12.45^{\mathrm{f}-\mathrm{h}} \pm 0.08$ & $12.32^{\mathrm{b}} \pm 0.18$ \\
\hline Ukrainian wheat & $12.21^{\mathrm{i}-\mathrm{k}} \pm 0.12$ & $12.61^{\mathrm{ef}} \pm 0.03$ & $12.93^{\mathrm{d}} \pm 0.10$ & $12.57^{\mathrm{eg}} \pm 0.06$ & $13.67^{\mathrm{a}} \pm 0.06$ & $12.80^{\mathrm{a}} \pm 0.52$ \\
\hline Interval mean $\pm \mathrm{SD}$ & $12.28^{\mathrm{b}} \pm 0.70$ & $12.43^{\mathrm{a}} \pm 0.67$ & $12.35^{\mathrm{ab}} \pm 0.81$ & $12.30^{\mathrm{b}} \pm 0.48$ & $12.33^{\mathrm{ab}} \pm 0.99$ & $12.34 \pm 0.72$ \\
\hline \multicolumn{7}{|l|}{ LSD 0.05} \\
\hline \multicolumn{2}{|c|}{ Among [Origin (O.)] } & \multicolumn{3}{|c|}{ Among [interval (I.)] } & \multicolumn{2}{|c|}{ Interaction (O. X I.) } \\
\hline \multicolumn{2}{|c|}{$0.12 * *$} & \multicolumn{3}{|c|}{$0.11 * *$} & \multicolumn{2}{|l|}{$0.18 * *$} \\
\hline
\end{tabular}

- Data are expressed as means (3 replicates) \pm SD.

- Averages of origin in the same column having the same superscripts are not significantly different, same averages in interval raw which having same superscripts are not significantly different at $\mathrm{P} \leq 0.05$.

in three categories, highest level was noted in both Romanian and Ukrainian wheat with an average of 12.90 and $12.80 \%$ respectively, without significant differences between them. Romanian wheat contained $12.17-13.34 \%$ of protein content and Ukrainian wheat contained 12.21-13.67\% of protein content.
Protein content in the Russian wheat was less than both Romanian and Ukrainian wheat with an average of $12.32 \%$ with a range between $12.03-12.45 \%$. While French wheat samples scored least protein content among other wheat samples as the average of protein content in different intervals was $11.34 \%$ and it was in the range of $11.02-$ 
$11.54 \%$ interval two which was between September to October contained highest levels of protein content $(12.43 \%)$ without significant differences with third and fifth intervals, while lowest protein content was scored in the first interval $(12.28 \%)$ without significant differences with fourth interval.

Protein content of the discussed samples was in the range of $11.02-13.67 \%$ and all samples considered as good wheat in producing bread, which was in line with the findings of Khan et al. (2013), who studied wheat of different sources in Pakistan and found it to contain $10.4-14.6 \%$ of protein content.

Ukrainian wheat protein content ranged from $12.21 \%$ to $13.67 \%$ with an average of $12.80 \%$ comparing to $12.32,12.90$ and $11.34 \%$ for Russian, Romanian and French wheat samples, respectively. Within the Ukrainian wheat samples, $5^{\text {th }}$ interval got the biggest protein content (13.67\%) while $1^{\text {st }}$ interval was the minimum protein content $(12.21 \%)$.

Protein content of the imported Russian wheat was in the range $12.03-12.45 \%$ with an average of $12.32 \%$.Within this wheat origin country (Russia) first interval scored the minimum protein content $(12.03 \%)$ followed by both third and fourth intervals with significant differences with scores (12.31 and $12.38 \%)$ respectively, for third and fourth intervals, maximum protein content was that of the $5^{\text {th }}$ interval $(12.45 \%)$.

Romanian wheat samples' protein content were not significantly deferent than those of Ukrainian wheat samples with an average of $12.90 \%$. Protein content of the imported Romanian wheat was in the range 12.17$13.34 \%$. Within this wheat origin country (Romania) first interval scored the maximum Protein content (13.34\%) followed by both second and third intervals with significant differences (13.23 and 13.05\%), respectively for second and third intervals, minimum
Protein content was that of the $5^{\text {th }}$ interval (12.17\%).

Protein content of the imported French wheat were in the range $11.02-11.54 \%$ within an average of $11.34 \%$.Within this wheat origin country (French) fourth interval scored the maximum protein content $(11.54 \%)$ followed by first and second intervals with significant differences with scores 11.53 and $11.48 \%$, respectively for first and second intervals, minimum protein content was that of the $5^{\text {th }}$ interval $(11.02 \%)$.

EOS (2015) states that Protein content should not less than $11 \%$, and the results indicated that all wheat's from Ukraine, Russia, Romania and France is acceptable imported wheat's, and both Romanian and Ukrainian wheat's achieved highest level with an average of 12.90 and $12.80 \%$, respectively.

\section{Conclusions}

The study focused on putting our fingers on some sorts of wheat that Egypt import, recognizing how these freights correspond with the Egyptian standards and scientifically know, the best kinds of wheat for human consumption and organizing the exporting countries up to the best quality for making a loaf of bread in Egypt. and obtained results indicated that the Ukrainian wheat was the beast among all other wheat originated from France, Romania and Russia, followed by French wheat, Russian wheat and lastly Romanian wheat in most tests used (moisture content, test weight, falling number, and came in the second step in protein content and Shrunken and broken grains and came in the third step in insect damaged kernels). Finally it is recommended to increase importing Ukrainian wheat, with an alert on the application of the exact fumigation doses of containers for shipments from Ukraine to avoid the insect loss. 


\section{REFERENCES}

AACC (1972). American Association of Cereal Chemists, Method 56-81B, Method 22-07. Approved methods of AACC, $7^{\text {th }}$ Ed. Ame. Assoc. Cereal Chem., St Paul, MN, USA.

AACC (2000). Approved Methods of American Association of Cereal Chemists, $10^{\text {th }}$ Ed. The Assoc., St. Paul, MN, USA.

Babić, L.; Babić, M.; Turan, J.; MatićKekić, S.; Radojčin, M.; MehandžićStanišić, S.; Pavkov, I. and Zoranović, M. (2011). Physical and stress-strain properties of wheat (Triticum aestivum) Kernel. J. Sci. Food and Agric., 91 : 1236-1243.

Brabec, D.L.; Pearson, T.C.; Maghirang, E.B. and Flinn, P.W. (2015). Detection of fragments from internal insects in wheat samples using a laboratory entoleter. Cereal Chem., 92: 8-13.

Chelladurai, V., Jayas D.S., White N. D., (2010). Thermal imaging for detecting fungal infection in stored wheat. J. Stored Prod. Res., 46:174-179.

Derera, N.F. (1989). The effects of preharvest rain. In: Derera, N.F. (Ed.), Preharvest Field Sprouting in Cereals. CRS Press Inc., Boca Raton, USA, 1-14.

Duncan, B.D. (1955). Multiple Ranges and Multiple F-tests. Biometric, 11: 1-42.

Edwards, R.A.; Ross, A.S.; Mares, D.J.; Ellison, F.W. and Tomlinson, J.D. (1989). Enzymes from rain-damaged wheat and laboratory-germinated wheat. I. Effects on product quality. J. Cereal Sci., 10: 157-167.

EOS (2015). Egyptian Organization for Standards. Standard Specification No. $1601 / 2005$ on basic requirements and descriptive criteria for wheat varieties. http://www.eos.org.eg
El-Fawal, Y.A.; Tawfik, M.A. and ElShal, A.M. (2009). Study on Physical and Engineering Properties for Grains of Some Field Crops. Misr J. Agric. Eng., 26: 1933-1951.

El-Naggar, S.M. and Mikhaiel, AA. (2011). Disinfestation of stored wheat grain and flour using gamma rays and microwave heating. J. Stored Prod. Res., 47 : 191-196.

Finney, P.L. (1985). Effect of wheat variety on the relationship between falling numbers and alpha-amylase activity. Cereal Chem., 62 (4): 258-262.

Geoff Honey (2010). Test Weight of Australian Wheat 2010 and Beyond, Industry briefing paper: 1-9. http://www. graintrade.org.au

Gerber, A. (2014). Food Security as an Outcome of Food Systems. http://www. systemdynamics.org

German, C.L. (2006). Understanding the Falling Number Wheat Quality Test. Extension Crops Marketing Specialist, University of Delaware, Newark, DE. http://www.northern-crops.com/technical/ fallingnumber.htm.

Grain Inspection Handbook II wheat chapter 13: 13-25, USA Department of agriculture.

Hagberg, S. (1960). A rapid method for determining alpha-amylase activity. Cereal Chem., 37: 2018.

Hagberg, S. (1961). Simplified method for determining a-amylase activity. Cereal Chem., 38: 202-203.

Husejin, K.; Mirsad, S.; Amra, O.; Midhat, J.; Nihada, A. and Indira, Š. (2008). The importance of determination of some physical- chemical properties of wheat and flour. Univ. of Tuzla, Fac. Technol., Agric. Conspectus. Sci., 74 (3): 197-200. 
ICC (1968). International Association of Cereal Science and Technology, Method 107, Method 108, Standard methods of ICC. Verlag Moritz Schafer, Detmold, FRG.

Khan, M.D.; Asaduzzaman, M.M.R.; Mousumi, T.; Nusrat, F.; Shoshee, A.X. and Han-chun, C. (2013). Antioxidative potential of duranta repens (linn.) fruits against $\mathrm{H}_{2} \mathrm{O}_{2}$ induced cell death in vitro. Afr. J. Tradit. Complement. Altern. Med., 10 (3): 436-441.

Kimball, B.A.; Morris, C.F.; Pinter, J.P.J.; Wall, G.W.; Hunsaker, D.J.; Adamsen, F.J.; LaMorte, R.L.; Leavitt, S.W.; Thompson, T.L.; Matthias, A.D. and Brooks, T.J. (2001). Elevated $\mathrm{CO}_{2}$, drought and soil nitrogen effects on wheat grain quality. New Phytol., 150: 295-303.

Kleijer, G.; Levy, L.; Schwaerzel, R.; Fossati, D. and Brabant, C (2007). Relationship between test weight and several quality parameters in wheat. Agrar Forchung, 14 (11-12): 548-553.

Ktenioudaki, A.; Butler, F. and Gallagher, E. (2010). Rheological properties and baking quality of wheat varieties from various geographical regions. J. Cereal Sci., 51: 402-408.

Lumpkin, T.A. (2011). Wheat-global alliance for improving food security and the livelihoods of the resource-poor in the developing world. Nat. Agric. Res. Inst.

Manley, M.; Engelbrecht, M.L.; Williams, P.C. and Kidd, M. (2009). Assessment of variance in the measurement of hectoliter mass of wheat, using equipment from different grain producing and exporting countries. Bio Systems Eng., 103: 176-186.

Michael, D.T.; Thomas, W.P. and Mark, E.P. (2005). Estimating populations of grain beetles using probe traps in wheat- filled concrete silos. Environ. Entomol., 34 (3): 712-718.

Michigan University (1983). Microcomputer Statistical Program, version 2. Michigan state university. East Linsing.

Natalja, P.; Avramenko, D.K. and Ilga, G. (2016). Investigation of immature wheat grain chemical composition. Res. Rural Dev., 1: 102-105.

Odette, L.S.; Glenn, A.B.; Robert, D.S.; Gail, M.S.; William, F.K.T. and Ronald, D.P. (1985). Deoxynivalenol in hard red winter wheat: relationship between toxin levels and factors that could be used in grading. J. Assoc. Off. Anal. Chem., 68 (5): 954-957.

Perten, H. (1964). Application of the falling number method for evaluating aamylase activity. Cereal Chem., 41: $127-140$.

Posner, E.S. and Hibbs, A.N. (2005). Wheat Flour Milling. AACC Inc., St. Paul.

Protic, R.; Mladen, M.; Nada, P.; Života, J. and Predrag, J. (2007). The test weight of several winter wheat genotypes under various sowing dates and nitrogen fertilizer rates. Inst. Sci. Application in Agric., Belgrade, Serbia.

Shewry, P.R.; Tatham, A.S.; Forde, J.; Kreis, M. and Miflin, B.J. (1986). te classification and nomenclature of wheat gluten proteins; A reassessment. J. Cer. Sci., 4: 97-106.

Singh, C.B.; Jayas, D.S.; Paliwal, J. and White, N.D.G. (2010). Identification of insect-damaged wheat kernels using short-wave near-infrared hyper spectral and digital colour imaging. Computers and Electronics in Agric., 73:118-125.

Snape, J.; Fish, L.; Leader, D.; Bradburne, R. and Turner, A. (2005). The impact of genomics and genetics on wheat quality improvement. Turk. J. Agr. For., 29: 97-103. 
Sramkova, Z.; Gregova, E. and Sturdik, E. (2009). chemical composition and nutrition Quality of wheat grain, Acta Chem. Sloraca, 2 (1): 115-138.

Steel, R.G.D. and Torrie, J.H. (1980). Principals and Procedures of Statistics: A Biometrical Approach $2^{\text {nd }}$ Ed. Mc. Graw-Hill Blook Co. New York.
Trajković, J.; Baras, J.; Mirić, M. and Šiler, S. (1983). Analyses of Food Products, TMF, Belgrad.

Zhao, C.X.; He, M.R.; Wang, Z.L.; Wang, Y.F. and Lin, Q. (2009). Effects of different water availability at post-an thesis stage on grain nutrition and quality in strong-gluten winter wheat. CR Biol., 332:759-764.

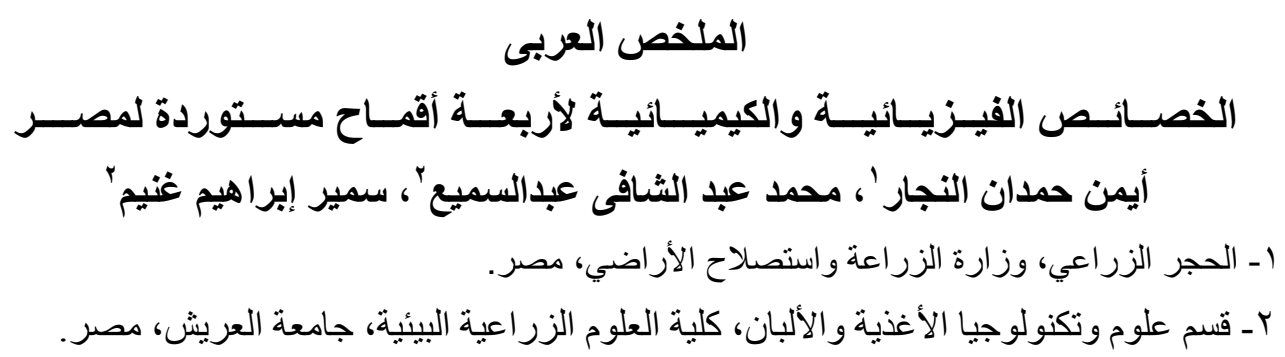

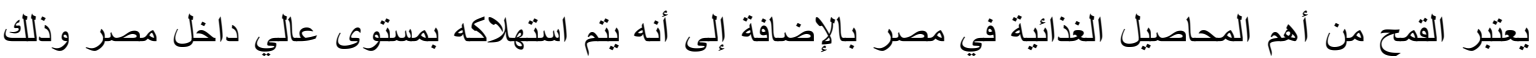

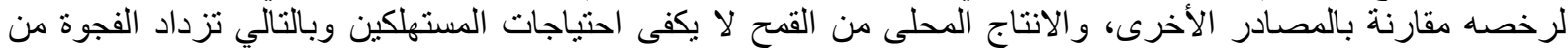

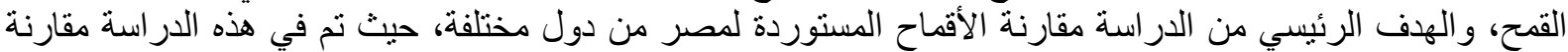

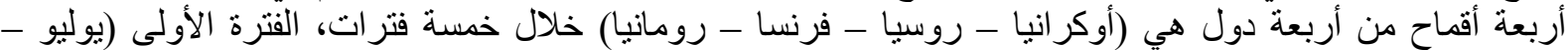

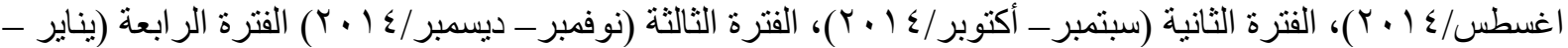

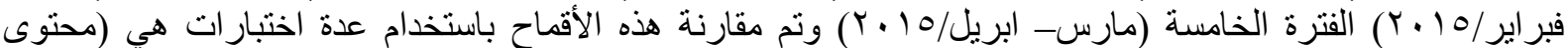

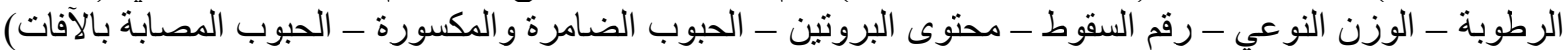

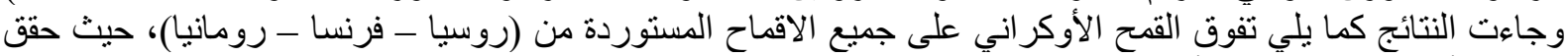

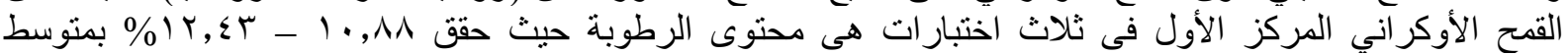

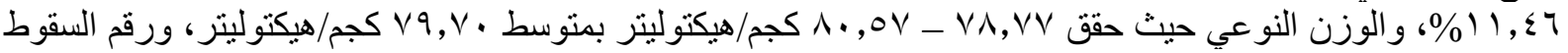

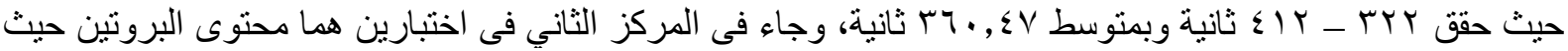

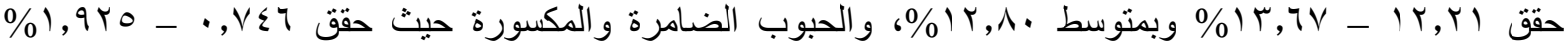

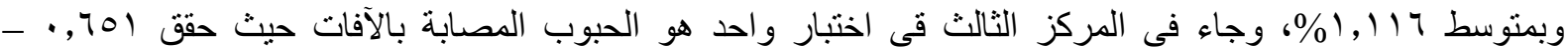

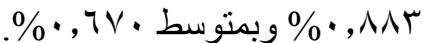

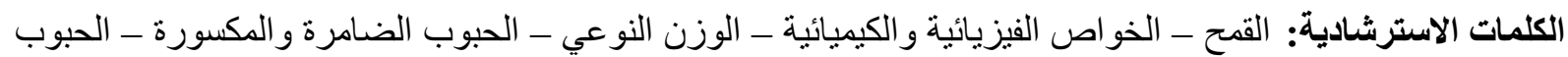
المصابة بالآفات ـ المحتوى الرطوبى ـ رقم السقوط - المحتوى البروتينى. 